\title{
DIMENSI RISIKO BAGI KONSUMEN DALAM MEMBELI PRODUK HALAL
}

\author{
${ }^{1}$ Setiawan, ${ }^{2}$ Diharpi Herli Setyowati, ${ }^{3}$ Fifi Afiyanti Tripuspitorini \\ ${ }^{1,2,3}$ Politeknik Negeri Bandung \\ Jalan Gegerkalong Hilir, Desa Ciwaruga, Bandung, Indonesia 40012 \\ ${ }^{1}$ setiawan@polban.ac.id, ${ }^{2}$ diharpi.herli@polban.ac.id, ${ }^{3}$ fifi.afiyanti@polban.ac.id
}

\begin{abstract}
Abstrak
Tujuan dari penelitian ini adalah untuk mengetahui berbagai risiko yang dapat mempengaruhi keputusan membeli produk halal. Untuk memperoleh data penelitian digunakan data primer dengan cara menyebar angket kepada responden yang tersebar di Kota Bandung. Alat analisis yang digunakan adalah dengan menggunakan SEM-PLS dan dibantu software SmartPLS. Hasil penelitian menunjukkan bahwa risiko kesehatan dan risiko waktu secara signifikan berpengaruh terhadap keputusan membeli produk halal. Sedangkan secara simultan diketahui bahwa seluruh variabel independen yaitu sebesar 39,3 persen dapat menjelaskan keputusan membeli produk halal.
\end{abstract}

Kata kunci: produk halal, risiko, keputusan membeli

\begin{abstract}
The purpose of this research is to find out various risks that can influence the decision to buy halal products. The research data used are primary data by distributing questionnaires to respondents scattered in the city of Bandung. The analytical tool used is to use SEM-PLS and assisted by SmartPLS software. The results showed that health risk and time risk significantly influence the decision to buy halal products. While simultaneously known that all independent variables, namely 39.3 percent, can explain the decision to buy halal products.
\end{abstract}

Keywords: halal products, risks, buying decisions

\section{Introduction}

Halal didefinisikan sebagai segala sesuatu yang diizinkan atau diterima oleh umat Islam(Zakaria \& Abdul-Talib, 2010). Penunjukan halal atau haram harus diterapkan pada setiap objek dan tindakan. Menurut ketentuan syariat, sebutan halal tersebut memberikan panduan bagi kita untuk semua aspek kehidupan(Jafari
\&Scott, 2014). Untuk menjadi aman dan sadar akan ketidakmurnian, individu harus mengikuti instruksi mengenai apa yang halal dan haram dalam Quran dan Sunnah(Annabi, Husein, \& Hassan, 2017). Orang harus mempertimbangkan apa yang halal dan haram untuk melindungi agama dan kehormatan mereka(Annabi et al., 2017). Menurut Marco (2011), individu

merasakan risiko konsumsi dan

Received: 2019-10-14 | Reviced: 2020-01-21 | Accepted: 2020-01-31

Indexed :Sinta, DOAJ, Garuda, Crossref, Google Scholar | DOI: https://doi.org/10.29313/amwaluna.v4i1.5220 
menghindari produk yang diragukan dan dipertanyakan.

Sebagian besar peneliti sebelumnya membahas mengenai konsep dan pentingnya pasar halal sebagai potensi bisnis global dan tren komersial baru karena pertumbuhan global populasi Muslim yang terus meningkat (Henderson, 2009). Nilai industri halal diperkirakan mencapai \$2,1 triliun per tahun dan membuatnya menjadi salah satu industri dengan pertumbuhan tercepat dalam beberapa tahun terakhir (Oktadiana, Pearce, \& Chon, 2016). Lebih lanjut, studi dalam Thompson Reuters (2015) mengemukakan bahwa pasar makanan halal global telah mencapai nilai \$ 1.128 miliar pada tahun 2014 dan diperkirakan angka ini terus naik sehingga dapat mencapai $\$ 1.585$ miliar pada tahun 2020. Volume bisnis pasar ini mencakup lebih dari lima puluh negara di seluruh dunia, yang menciptakan segmen pasar yang potensial dan menarik (Ryan, 2016).

Ketertarikan untuk mengembangkan pasar halal pada saat ini semakin meningkat dalam skala global (Al-Ansi, Olya, \& Han, 2018). Kesadaran dan pentingnya pasar ini terus meningkat selama beberapa tahun terakhir dengan banyaknya upaya dari para akademisi dalam sumbangsih keilmuan dan regulator dalam kaitannya dengan kebijakan bisnis (Jafari \& Scott, 2014).
Terlepas dari nilai pasar halal yang terus naik, pelaku bisnis dan pelanggan dinilai hanya memiliki sedikit pengetahuan tentang operasi dan implementasi fenomena kompleks yang berasal dari hukum Syariah Islam (Al-Ansi et al., 2018). Terutama dalam kaitannya dengan makanan halal. Sehingga, baik bagi para pelaku bisnis ataupun penyedia layanan sangat dibutuhkan wawasan yang lebih dalam mengenai sikap dan perilaku pelanggan halal (Rammal \& Zurbruegg, 2007).

Bagi konsumen halal yang beragama Islam, pilihan mereka akan tergantung pada interpretasi pribadi terhadap Al-Quran (Arsil, Tey, Brindal, Phua, \& Liana, 2018). Akibatnya, ada diversifikasi tentang bagaimana dan apa yang harus dimakan (Pradipta, 2016). Oleh karena itu, motivasi setiap Muslim adalah bagian integral dari kepatuhan dan penerapan halal dalam semua aspek kehidupan (Arsil et al., 2018). Niatan dari konsumen Muslim untuk mengukur sikap yang tepat dalam membeli makanan halal masih menjadi hal yang menarik dan terus diteliti (Awan, Siddiquei, \& Haider, 2015).

Sedangkan bagi konsumen non-Muslim, pilihan akan dikembalikan kepada individu masing-masing. Nilai-nilai pribadi dipandang sebagai faktor utama penggerak perilaku dalam melakukan pilihan (Hansson dan Lagerkvist, 2015). Konsumsi 
makanan dan produk halal dapat diperluas untuk mencakup berbagai segmen pasar seperti pelanggan Muslim dan non-Muslim karena keprihatinannya yang tinggi pada masalah kesehatan, lingkungan, dan kualitas (Olya \& Al-ansi, 2018). Ambali \& Bakar (2014) menemukan bahwa kesadaran pelanggan terhadap makanan dan produk halal cukup baik karena pelanggan menganggap produk halal lebih sehat. Kajian ini ingin meninjau lebih mendalam, sejauh mana konsumen menyadari pentingnya membeli produk halal bagi diri mereka. Sehingga dapat diketahui faktor penggerak individu atas kaitannya dengan kesadaran terhadap risiko yang menyertai pilihan dalam membeli produk halal.
Penelitian ini mengacu pada temuan AlAnsi et al., (2018); Olya \& Al-ansi, (2018) yang merupakan pengembangan dari Teori Persepsi Risiko (Perceived Risk) yang dipelopori oleh Cunningham (1967), bahwa dimensi Risiko meliputi: Risiko Kesehatan, Risiko Psikologi, Risiko Lingkungan, Risiko Sosial, Risiko Kualitas, Risiko Keuangan, dan Risiko Waktu.

\section{Dicussion}

Dari 200 kuesioner yang diharapkan hanya sekitar 183 yang layak untuk dapat diproses pada tahap selanjutnya. Tabel 1 di bawah ini menggambarkan karakteristik demografi dari responden yang mengkonsumsi produk halal.

Tabel 1

\section{Demografi Responden}

\begin{tabular}{|l|l|r|r|}
\hline Variabel & \multicolumn{1}{|c|}{ Deskripsi } & Frekuensi & \% \\
\hline \multirow{4}{*}{ Gender } & Laki-laki & 39 & $21.31 \%$ \\
\cline { 2 - 4 } & Perempuan & 144 & $78.69 \%$ \\
\hline \multirow{5}{*}{ Umur } & $<20$ tahun & 24 & $13.11 \%$ \\
\cline { 2 - 4 } & $20-29$ tahun & 149 & $81.42 \%$ \\
\cline { 2 - 4 } & $30-39$ tahun & 4 & $2.19 \%$ \\
\cline { 2 - 4 } & $40-49$ tahun & 3 & $1.64 \%$ \\
\cline { 2 - 4 } & $>50$ tahun & 3 & $1.64 \%$ \\
\hline \multirow{5}{*}{ Pendidikan } & di bawah & 0 & $0.00 \%$ \\
\cline { 2 - 4 } & SMA/sederajat & 111 & $60.66 \%$ \\
\cline { 2 - 4 } & SMA/sederajat & 72 & $39.34 \%$ \\
\cline { 2 - 4 } & Sarjana & & \\
\hline
\end{tabular}

Sumber: data yang diolah, 2019

Berdasarkan tabel di atas dapat dilihat sebanyak 13,11 persen dan dominasi bahwa responden perempuan sebesar 78,69 terbesar adalah kelompok usia 20 - 29 yang persen dan laki-laki 21,31 persen. Umur mencapai 81,42 persen dan selebihnya di responden yang di bawah 20 tahun atas usia 30 tahun. Sedangkan pendidikan Received: 2019-10-14 | Reviced: 2020-01-21 | Accepted: 2020-01-31 Indexed :Sinta, DOAJ, Garuda, Crossref, Google Scholar | DOI: https://doi.org/10.29313/amwaluna.v4i1.5220 
responden didominasi oleh kelompok SMA sebanyak 60,66 persen dan selebihnya merupakan sarjana atau pascasarjana dengan presentase sebanyak 39,34 persen. Untuk melihat validitas dan reliabilitas instrumen kuesioner, maka dipergunakan
Outer Loadings, Cronbach's Alpha dan Composite Reliability (CR), dan Average Variance Extracted (AVE). Adapun hasilnya adalah sebagai berikut.

Tabel 2

Loading of the Item Measurement, Cronbach's Alpha, Composite Reliability (CR) and AVE

\begin{tabular}{|c|c|c|c|c|}
\hline Construct/Item & $\underset{*}{\text { Loading }}$ & $\begin{array}{l}\text { Cronb } \\
\operatorname{ach} \alpha\end{array}$ & CR & AVE \\
\hline Risiko Kesehatan & & 0.933 & 0.952 & 0.834 \\
\hline $\begin{array}{l}\text { - Saya khawatir tentang risiko terhadap kesehatan saya } \\
\text { jika saya tidak mengkonsumsi barang halal }\end{array}$ & 0.879 & & & \\
\hline $\begin{array}{l}\text { - Saya khawatir akan rentan terhadap penyakit } \\
\text { epidemi jika tidak mengkonsumsi barang halal }\end{array}$ & 0.909 & & & \\
\hline $\begin{array}{l}\text { - Saya khawatir tentang mengkonsumsi barang-barang } \\
\text { non-halal yang tidak sehat }\end{array}$ & 0.932 & & & \\
\hline $\begin{array}{l}\text { - Saya khawatir tentang mengkonsumsi barang-barang } \\
\text { non-halal yang berbahaya }\end{array}$ & 0.931 & & & \\
\hline Risiko Psikologis & & 0.918 & 0.948 & 0.859 \\
\hline $\begin{array}{l}\text { - Pikiran untuk mengkonsumsi barang-barang non- } \\
\text { halal membuat saya merasa cemas }\end{array}$ & 0.945 & & & \\
\hline $\begin{array}{l}\text { - Pikiran mengonsumsi barang-barang non-halal } \\
\text { membuat saya merasa tidak nyaman secara } \\
\text { psikologis }\end{array}$ & 0.946 & & & \\
\hline $\begin{array}{l}\text { - Pikiran mengkonsumsi barang-barang non-halal } \\
\text { menyebabkan saya mengalami ketegangan yang } \\
\text { tidak perlu }\end{array}$ & 0.888 & & & \\
\hline Risiko Lingkungan & & 0.902 & 0.936 & 0.830 \\
\hline $\begin{array}{l}\text { - Saya prihatin dengan kondisi lingkungan di mana } \\
\text { barang halal diproduksi dan diproses }\end{array}$ & 0.928 & & & \\
\hline - Saya prihatin dengan standar kebersihan barang halal & 0.912 & & & \\
\hline $\begin{array}{l}\text { - Saya prihatin dengan kondisi fisik di mana barang- } \\
\text { barang halal disimpan dan dijual }\end{array}$ & 0.893 & & & \\
\hline Risiko Sosial & & 0.951 & 0.918 & 0.790 \\
\hline $\begin{array}{l}\text { - Saya khawatir bahwa mengkonsumsi barang halal } \\
\text { tidak akan kompatibel dengan citra diri saya }\end{array}$ & 1.000 & & & \\
\hline $\begin{array}{l}\text { - Saya khawatir bahwa mengkonsumsi barang halal } \\
\text { akan mengubah cara teman saya memikirkan saya }\end{array}$ & 0.833 & & & \\
\hline $\begin{array}{l}\text { - Saya khawatir bahwa mengkonsumsi barang halal } \\
\text { tidak akan konsisten dengan status saya (kelas sosial) }\end{array}$ & 0.823 & & & \\
\hline Risiko Kualitas & & 0.952 & 0.968 & 0.911 \\
\hline - Saya khawatir tentang integritas barang dan penjual & 0.934 & & & \\
\hline
\end{tabular}




\begin{tabular}{|c|c|c|c|c|}
\hline Construct/Item & $\underset{*}{\text { Loading }}$ & $\begin{array}{l}\text { Cronb } \\
\text { ach } \alpha\end{array}$ & CR & AVE \\
\hline \multicolumn{5}{|l|}{ halal dan tentang kualitas barang } \\
\hline $\begin{array}{l}\text { - Saya khawatir kualitas barang halal kurang dari yang } \\
\text { saya harapkan }\end{array}$ & 0.974 & & & \\
\hline $\begin{array}{l}\text { - Saya khawatir kualitas barang halal tidak sesuai } \\
\text { dengan deskripsi yang diberikan pada paket dan } \\
\text { iklan }\end{array}$ & 0.955 & & & \\
\hline Risiko Keuangan & & 0.952 & 0.969 & 0.911 \\
\hline $\begin{array}{l}\text { - Saya khawatir bahwa konsumsi barang halal akan } \\
\text { melibatkan pengeluaran tambahan yang tidak terduga }\end{array}$ & 0.962 & & & \\
\hline $\begin{array}{l}\text { - Saya khawatir barang halal akan lebih mahal } \\
\text { daripada barang non-halal }\end{array}$ & 0.939 & & & \\
\hline $\begin{array}{l}\text { - Saya khawatir bahwa biaya tambahan harus } \\
\text { dibayarkan ketika saya membeli barang halal }\end{array}$ & 0.963 & & & \\
\hline Risiko Waktu & & 0.980 & 0.987 & 0.962 \\
\hline $\begin{array}{l}\text { - Saya khawatir bahwa konsumsi barang halal akan } \\
\text { membuang-buang waktu }\end{array}$ & 0.978 & & & \\
\hline $\begin{array}{l}\text { - Saya khawatir perencanaan pembelian barang halal } \\
\text { akan memakan waktu terlalu lama }\end{array}$ & 0.988 & & & \\
\hline $\begin{array}{l}\text { - Saya khawatir persiapan barang halal akan memakan } \\
\text { waktu terlalu banyak }\end{array}$ & 0.977 & & & \\
\hline Keputusan membeli & & 0.731 & 0.844 & 0.657 \\
\hline $\begin{array}{l}\text { - Saya berniat untuk terus membeli barang halal di } \\
\text { masa depan }\end{array}$ & 0.924 & & & \\
\hline $\begin{array}{l}\text { - Saya akan terus membeli barang halal sebanyak } \\
\text { mungkin di masa depan }\end{array}$ & 0.922 & & & \\
\hline $\begin{array}{l}\text { - Saya akan mempertimbangkan kembali barang halal } \\
\text { sebagai prioritas dalam kebutuhan saya di masa } \\
\text { depan }\end{array}$ & 0.515 & & & \\
\hline
\end{tabular}

Sumber: data yang diolah, 2019

Berdasarkan pengujian yang disajikan pada tabel di atas, dapat dilihat bahwa Outer Loadings untuk semua indikator menunjukkan angka di atas 0,5 sehingga layak untuk menjadi representasi setiap variabel laten. Selanjutnya nilai AVE untuk semua variabel bernilai di atas 0,5 .
Sedangkan nilai Cronbach's Alpha untuk semua variabel bernilai di atas 0.7 , sama halnya dengan nilai $\mathrm{CR}$ yang bernilai di atas 0,7 yang artinya hal tersebut menunjukan nilai konsistensi dari masingmasing indikator dalam mengukur konstruknya (Hair et. al. , 2017). 
Tabel3

Heterotrait-Monotrait Ratio (HTMT)

\begin{tabular}{|l|c|c|c|c|c|c|c|c|}
\hline & $\begin{array}{c}\text { Risiko } \\
\text { Ling- } \\
\text { kungan }\end{array}$ & $\begin{array}{c}\text { Risiko } \\
\text { Keua- } \\
\text { ngan }\end{array}$ & $\begin{array}{c}\text { Risiko } \\
\text { Kese- } \\
\text { hatan }\end{array}$ & $\begin{array}{c}\text { Risiko } \\
\text { Psiko- } \\
\text { logi }\end{array}$ & $\begin{array}{c}\text { Kepu- } \\
\text { tusan } \\
\text { Mem- } \\
\text { beli }\end{array}$ & $\begin{array}{c}\text { Risiko } \\
\text { Kua- } \\
\text { litas }\end{array}$ & $\begin{array}{c}\text { Risiko } \\
\text { Sosial }\end{array}$ & $\begin{array}{c}\text { Risiko } \\
\text { Waktu }\end{array}$ \\
\hline $\begin{array}{l}\text { Risiko } \\
\text { Lingkungan }\end{array}$ & 0.437 & & & & & & & \\
\hline $\begin{array}{l}\text { Risiko } \\
\text { Keuangan }\end{array}$ & 0.310 & 0.127 & & & & & & \\
\hline $\begin{array}{l}\text { Risiko } \\
\text { Kesehatan }\end{array}$ & 0.277 & 0.086 & 0.762 & & & & & \\
\hline Risiko Psikologi & 0.211 & 0.121 & 0.682 & 0.524 & & & & \\
\hline $\begin{array}{l}\text { Keputusan } \\
\text { Membeli }\end{array}$ & 0.738 & 0.562 & 0.207 & 0.173 & 0.180 & & & \\
\hline Risiko Kualitas & 0.649 & 0.653 & 0.131 & 0.145 & 0.164 & 0.730 & & \\
\hline Risiko Sosial & 0.414 & 0.850 & 0.091 & 0.097 & 0.190 & 0.560 & 0.757 & \\
\hline Risiko Waktu & 0.967 & & & & & \\
\hline
\end{tabular}

Sumber: data yang diolah, 2019

Tabel 3 menunjukkan bahwa discriminant

validity dari variabel penelitian yang digunakan dapat diterima karena tidak ada nilai HTMT yang lebih dari 0,9 (Henseler, Ringle, \& Sarstedt, 2015). Melalui semua pengujian di atas dapat disimpulkan bahwa seluruh variabel valid dan reliabel serta layak untuk dilanjutkan dalam pengujian. Untuk mengukur rata-rata geometrik dari persamaan maka dilihat Goodness of Fit (GoF). Selain itu perlu dilihat pula nilai $\mathrm{R}^{2}$ untuk menilai seberapa baik model dalam penelitian ini bisa menjadi prediktor.

Tabel 4

Goodness of Fit (GoF) Index

\begin{tabular}{|l|c|c|}
\hline \multicolumn{1}{|c|}{ Variabel } & AVE & $\boldsymbol{R}^{2}$ \\
\hline Risiko Kesehatan & 0.834 & \\
\hline Risiko Psikologi & 0.859 & \\
\hline Risiko Lingkungan & 0.830 & \\
\hline Risiko Sosial & 0.790 & \\
\hline Risiko Kualitas & 0.911 & \\
\hline
\end{tabular}

\begin{tabular}{|l|c|c|}
\hline \multicolumn{1}{|c|}{ Variabel } & AVE & $\boldsymbol{R}^{\mathbf{2}}$ \\
\hline Risiko Keuangan & 0.911 & \\
\hline Risiko Waktu & 0.962 & \\
\hline Keputusan Membeli & 0.657 & 0.393 \\
\hline Average score & 0.844 & 0.393 \\
\hline AVE $\times \boldsymbol{R}^{\mathbf{2}}$ & & 0.332 \\
\hline GoF $=\sqrt{\left(\mathrm{AVE} \times \boldsymbol{R}^{\mathbf{2}}\right)}$ & & 0.576 \\
\hline
\end{tabular}

Sumber: data yang diolah, 2019

Standar untuk mengevaluasi hasil analisis GoF adalah kecil $(0,02)$, sedang $(0,25)$ dan besar (0,36) (Hair et al., 2017). Dalam penelitian ini, nilai GoF sebesar 0,715 (lihat tabel 4) menunjukkan bahwa model hubungan yang diusulkan dalam keputusan membeli produk halal adalah besar, ini menandakan bahwa model tersebut berkinerja relatif baik dan dapat dijadikan prediktor yang baik pula.

Untuk melihat seberapa besar kontribusi pengaruh yang diberikan seluruh variabel independen terhadap variabel 
dependen (keputusan membeli produk halal) maka dapat dilihat melalui $\mathrm{R}^{2}$. Nilai $\mathrm{R}^{2}$ untuk keputusan sebesar 0,393 atau sebesar 39,3 persen, sehingga dapat disimpulkan bahwa seluruh variabel independen yang diteliti dapat menjelaskan 39,3 persen keputusan konsumen dalam membeli produk halal. Selain untuk melihat seberapa besar pengaruh, $\mathrm{R}^{2}$ juga dapat dipakai sebagai alat prediktor yang baik.

Tabel 5

Path coefficient

\begin{tabular}{|l|c|c|c|}
\hline \multicolumn{1}{|c|}{ Path } & Coefficient & t-Stat & P Values \\
\hline Risiko Kesehatan => Keputusan Membeli & 0.568 & 5.708 & $0.000^{*}$ \\
\hline Risiko Psikologi => Keputusan Membeli & 0.062 & 0.916 & 0.360 \\
\hline Risiko Lingkungan => Keputusan Membeli & -0.052 & 0.616 & 0.538 \\
\hline Risiko Sosial => Keputusan Membeli & 0.134 & 1.408 & 0.160 \\
\hline Risiko Kualitas => Keputusan Membeli & 0.066 & 1.020 & 0.308 \\
\hline Risiko Keuangan => Keputusan Membeli & -0.047 & 0.452 & 0.651 \\
\hline Risiko Waktu => Keputusan Membeli & -0.187 & 1.709 & $0.088^{* *}$ \\
\hline
\end{tabular}

Sumber: data yang diolah, 2019

Tabel 5 menunjukkan pengaruh setiap variabel terhadap variabel keputusan. Hasil pengujian menyatakan bahwa faktor yang berpengaruh terhadap keputusan membeli produk halal adalah risiko kesehatan dengan koefisien sebesar 0.568 yang signifikan pada $\mathrm{p}<0.01$ atau $1 \%$. Selanjutnya adalah risiko waktu dengan koefisien -0.187 yang signifikan pada $\mathrm{p}<0.10$ atau $10 \%$. Sedangkan faktor lain tidak berpengaruh karena nilai signifikansinya ada pada $\mathrm{p}>0.01$, bahkan masih di atas 5\% (p>0.05) ataupun 10\% $(p>0.10)$.

Konsumen produk halal terutama dalam bentuk makanan sangat khawatir terhadap produk yang mereka beli. Walaupun Kota Bandung merupakan kota dengan mayoritas Muslim di Indonesia, namun konsumen menganggapnya hal tersebut bukan jaminan bahwa semua produk terutama yang halal dapat terjamin keamanan dan kesehatannyta. Apalagi bila produk tersebut berupa daging, yang merupakan produk hasil sembelihan hewan. Persepsi risiko kesehatan yang dimiliki konsumen sangat dominan mempengaruhi keputusan untuk membeli produk tersebut. Hal ini menguatkan temuan Fuseini, Wotton, Knowles, dan Hadley (2017) yang mengemukakan bahwa Muslim Inggris sangat tertekan dengan bahan makanan beredar yang dapat mengganggu kesehatan mereka. Bisa disebut bahwa persepsi risiko kesehatan ini terkait erat dengan kepercayaan konsumen terhadap penyedia produk. 
Namun di sisi lain, konsumen pun tidak memiliki waktu yang cukup untuk membuktikan bahwa produk yang mereka beli telah benar-benar aman bagi mereka. Sehingga risiko waktu menjadi hal turut signifikan mempengaruhi konsumen dalam keputusannya membeli produk halal. Temuan ini sejalan dengan penelitian Bonne dan Verbeke (2006) serta Bonne, Vermeir, Bergeaud-Blackler, dan Verbeke (2007) yang menyebutkan bahwa konsumen mungkin perlu menghabiskan lebih banyak waktu dan upaya dalam menemukan, membeli, dan mengkonsumsi barang halal, sehingga mereka akan merasakan kerugian waktu.

Sedangkan pengaruh persepsi risiko yang diteliti, yaitu meliputi risiko kesehatan, risiko psikologi, risiko lingkungan, risiko sosial, risiko kualitas, risiko keuangan, dan risiko waktu adalah ebesar 0,393. Hal tersebut berarti variabel risiko yang diteliti dapat menjelaskan sebesar 39,3 persen variabel keputusan membeli produk halal. Secara keseluruhan pengaruh tersebut terbilang rendah, sehingga sekitar 60,7 persen keputusan membeli produk dipengaruhi faktor lain yang tidak disertakan pada penelitian ini.

\section{Conclusion}

Berdasarkan pembahasan pada bab sebelumnya maka dapat disimpulkan bahwa bahwa faktor yang berpengaruh terhadap keputusan membeli produk halal adalah risiko kesehatan dengan koefisien sebesar 0.568 yang signifikan pada $\mathrm{p}<0.01$ atau $1 \%$. Selanjutnya adalah risiko waktu dengan koefisien -0.187 yang signifikan pada $\mathrm{p}<0.10$ atau $10 \%$. Sedangkan faktor lain tidak berpengaruh karena nilai signifikansinya ada pada $\mathrm{p}>0.01$, bahkan masih di atas 5\% (p>0.05) ataupun $10 \%$ $(\mathrm{p}>0.10)$.

Penting bagi penyedia produk halal untuk memberikan keyakinan pada konsumen bahwa produk yang mereka jual telah memenuhi berbagai proses pengujian yang sesuai standar. Sehingga produk yang mereka jual dapat dinilai telah memenuhi aspek kesehatan dan keamanan.

Dapat dirancang penelitain selanjutnya dengan responden di berbagai kota atau wilayah lain dengan jumlah yang lebih besar. Selain itu dapat pula dicari faktor lain yang mungkin lebih dapat berkontribusi terhadap keputusan konsumen dalam membeli produk halal.

\section{Bibliografhy}

Al-Ansi, A., Olya, H. G. T., \& Han, H. (2018). Effect of general risk on trust, satisfaction, and recommendation intention for halal food. International Journal of Hospitality Management.

Ambali, A. R., \& Bakar, A. N. (2014). People's Awareness on Halal Foods and Products: Potential Issues for 
Policy-makers. Procedia - Social and Behavioral Sciences, 121, 3-25.

Annabi, C. A., Husein, M. U., \& Hassan, F. (2017). Sharia Compliance in the Construction Industry: Is this Something to Build Upon? Journal of Emerging Economies and Islamic Research, 5(1), 1-15.

Arsil, P., Tey, Y. S., Brindal, M., Phua, C. U., \& Liana, D. (2018). Personal values underlying halal food consumption: evidence from Indonesia and Malaysia. British Food Journal.

Awan, H. M., Siddiquei, A. N., \& Haider, Z. (2015). Factors affecting Halal purchase intention - evidence from Pakistan's Halal food sector. Management Research Review, 38(6), 640-660.

Bonne, K., \& Verbeke, W. (2006). Muslim consumer's motivations towards meat consumption in Belgium: Qualitative exploratory insights from means-end chain analysis. Anthropology of Food, (5).

Bonne, K., Vermeir, I., Bergeaud-Blackler, F., \& Verbeke, W. (2007). Determinants of halal meat consumption in France. British Food Journal, 109(5), 367-386.

Fuseini, A., Wotton, S. B., Knowles, T. G., \& Hadley, P. J. (2017). Halal meat fraud and safety issues in the UK: A review in the context of the European union. Food Ethics, 1-16

Hair, J.F., Hult, G.T.M., Ringle, C.M. and Sarstedt, M. (2017). A Primer on Partial Least Squares Structural Equation Modeling (PLS-SEM).Sage. Los Angeles.
Henderson, J. C. (2009). Islamic Tourism Reviewed. Tourism Recreation Research, 34(2), 207-211.

Henseler, J., Ringle, C. M., \& Sarstedt, M. (2015). A new criterion for assessing discriminant validity in variance-based structural equation modeling. Journal of the Academy of Marketing Science, 43(1), 115-135.

Jafari, J., \& Scott, N. (2014). Muslim world and its tourisms. Annals of Tourism Research, 44, 1-19.

Marco, T. (2011). The application of Halal in supply chain management: in-depth interviews. Journal of Islamic Marketing, 2(2), 186-195.

Oktadiana, H., Pearce, P. L., \& Chon, K. (2016). Muslim travellers , needs: What don' t we know?, 20(124-130), 2015-2017.

Olya, H. G. T., \& Al-ansi, A. (2018). Risk assessment of halal products and services: Implication for tourism industry. Tourism Management, 65, 279-291.

Rammal, H. G., \& Zurbruegg, R. (2007). Awareness of Islamic banking products among Muslims: The case of Australia. Journal of Financial Services Marketing, 12(1), 65-74.

Ryan, C. (2016). Editorial. Tourism Management Perspectives, 19(PB), 121-123.

Zakaria, N., \& Abdul-Talib, A. N. (2010). Applying Islamic market-oriented cultural model to sensitize strategies towards global customers, competitors, and environment. Journal of Islamic Marketing, 1(1), 51-62. 